\title{
Article \\ Does the Urban Environment Act as a Filter on the Individual Quality of Birds?
}

\author{
Agnès Saulnier ${ }^{1, *}$, Josefa Bleu ${ }^{1,2} \mathbb{D}$, Gildas Lemonnier ${ }^{1,2}$, Pierre Uhlrich ${ }^{1,2}$, Sandrine Zahn ${ }^{1,2}$ (D) \\ and Sylvie Massemin ${ }^{1,2}$
}

check for updates

Citation: Saulnier, A.; Bleu, J.; Lemonnier, G.; Uhlrich, P.; Zahn, S.; Massemin, S. Does the Urban Environment Act as a Filter on the Individual Quality of Birds? Birds 2022, 3, 84-98. https://doi.org/ $10.3390 /$ birds3010007

Academic Editor: Jukka Jokimäki

Received: 30 November 2021

Accepted: 26 January 2022

Published: 5 February 2022

Publisher's Note: MDPI stays neutral with regard to jurisdictional claims in published maps and institutional affiliations.

Copyright: (C) 2022 by the authors. Licensee MDPI, Basel, Switzerland. This article is an open access article distributed under the terms and conditions of the Creative Commons Attribution (CC BY) license (https:// creativecommons.org/licenses/by/ $4.0 /)$.
1 Département d'Ecologie, Physiologie et Ethologie, Institut Pluridisciplinaire Hubert Curien, UMR 7178 CNRS-Université de Strasbourg, F-67000 Strasbourg, France; josefa.bleu@iphc.cnrs.fr (J.B.); gildas.lemonnier@iphc.cnrs.fr (G.L.); pierre.uhlrich@iphc.cnrs.fr (P.U.); sandrine.zahn@iphc.cnrs.fr (S.Z.); sylvie.massemin@iphc.cnrs.fr (S.M.)

2 ZAEU, Maison Interuniversitaire des Sciences de 1'Homme-Alsace (MISHA), 5, allée du Général Rouvillois, CS 50008, CEDEX, 67083 Strasbourg, France

* Correspondence: agnes.saulnier@iphc.cnrs.fr

Simple Summary: The urban environment is considered to be challenging for urban birds due to the deep modification of biotic and abiotic factors compared to natural habitats. However, some studies on physiology have showed that urban breeders appear to be of better health than rural breeders. A hypothesis can explain these results: cities act as a filter on individuals, and only the best-performing birds can access and succeed in reproduction. To test this hypothesis, we compared the quality of urban and forest Great Tits before and during breeding to highlight potential differences between the general population (winter) and breeders in each site. Quality was estimated from body size and body condition, as well as telomere length, a DNA marker of bird health and longevity. No differences in body condition were observed. However, urban birds were smaller than forest birds, and, in the city only, breeders were smaller than birds captured in winter. These results highlight that urban habitats potentially favor smaller birds. Finally, urban individuals had longer telomeres than forest ones, but only in winter. The decrease in telomere length between winter and reproduction only in the city suggests a higher cost of reproduction in the city compared to the forest.

\begin{abstract}
Phenotypic divergences of birds are common between urban and natural habitats and can result from different selective pressures between habitats or maladaptation to the city. No uniform patterns were observed, especially concerning markers of bird health, such as, for example, telomere length. Telomeres are involved in maintaining genome integrity and naturally shorten with age, but environmental stressors can accelerate their attrition. Thus, telomere length can be an indicator of individual quality. Some studies showed that urban breeders had longer telomeres than forest individuals. Two hypotheses can explain this result: (1) urban breeders are younger than forests breeders, and (2) cities act as a filter on individuals and only high-quality birds can successfully reproduce. In this context, we compared the age category (molting pattern) and morphological and physiological characteristics of urban and forest Great Tits before and during breeding. No differences in age or body condition were observed. However, urban breeders were smaller and had shorter telomeres than birds captured in winter. Urban birds had longer telomeres than forest birds, only in winter. These results highlight that urban habitats potentially favor smaller birds. However, the decrease in telomere length between winter and reproduction only in the city suggest a higher cost of reproduction in the city compared to the forest.
\end{abstract}

Keywords: urbanization; telomere; selection; Parus major; individual quality

\section{Introduction}

Each individual must optimize the energy allocation between survival and reproductive investment in order to maximize its fitness because resources are limited in the 
field [1,2]. These optimized trade-offs between somatic maintenance and reproduction depend on individual capacity to exploit these resources [3]. Some individuals more efficient in resource acquisition are able to reduce the trade-off and allocate energy to both reproduction and self-maintenance, allowing high reproductive success while limiting the impact of reproduction on their survival $[4,5]$. These individuals are so-called of better 'quality', and will display a higher level of individual performance [5,6]. In this case, phenotypic traits such as morphological, physiological and behavioral ones are positively correlated with both fitness components, namely reproduction and survival [6,7]. Heterogeneity in individual quality and performance will therefore depend on environmental constraints. To some extent, resource limitations will favor good-quality individuals which are able to survive and reproduce, while poor-quality individuals exhibit high reproductive costs [6]. However, too harsh conditions may decrease the heterogeneity due to the important mortality of poor-quality birds, leading to a homogenization of the phenotypes. For a given phenotype, individual performance can also fluctuate with age and/or experience [8-10]. This implies that individual quality can vary over time. In fact, experimented birds tend to have a better reproductive success than first-year breeders $[8,11,12]$, and the maturation hypothesis [13] supports the suggesting that this may be due to improvements in some skills, such as foraging ability [12], better timing of reproduction [14,15], or the increasing efficiency of the endocrine system (i.e., increase in prolactin levels) [16].

The urban environment, whose area extent is increasing every year with human population expansion (United Nations 2018), is considered to be challenging for urban birds [17-19] due to its deep modification of biotic and abiotic factors compared to natural habitats. In fact, among other things, urbanization leads to habitat fragmentation and a significant decrease in vegetal cover, as well as an increasing lighting duration and noise levels, a local temperature increase and chronic exposure to numerous toxic chemical compounds [20]. Changes in interspecific relationships have also been observed, resulting in a decrease in invertebrate availability during bird reproduction [21,22] or the modification of predator species, with a higher prevalence of opportunist nest predators [23] such as corvid predators [24,25] and mesopredators such as feral cats [26,27]. Modified avian productivity is also observed in cities [28,29]. Some studies have reported a decreasing reproductive success among passerine birds [18,30-32], while others showed no difference or a better reproductive success rate [29]. Even when buildings, artificial nest boxes or human structures offer new nesting opportunities, especially for cavicole species [24], insect availability during the breeding period remains lower [22,33], and food nutritional quality is inadequate [34-36]. Thus, the energy expenditure associated with foraging is higher in the city [36,37], as well as parental nest attendance [38], potentially leading to higher energy expenditure for urban birds than forest birds.

At the scale of bird communities, moderate urbanization leads to an increase in species richness [39]. All the same, homogenization of bird communities has been observed in cities, with the same urban-tolerant species thriving from one site to another $[40,41]$ and exhibiting similar functional traits $[42,43]$. For these urban-tolerant species, physiological and morphological divergences are observed in many studies when comparing rural and urban populations [29]. Among these differences, many studies have shown that urban birds are often smaller and lighter than their rural counterparts $[18,44,45]$, although this pattern is not always recurrent [46]. The question of the adaptive functions of these morphological divergences remains open. In the one hand, higher food predictability in cities due to anthropogenic food provisioning reduces the necessity of energetic reserves [47], leading to lighter birds. Smaller and lighter birds are able to escape from predators more quickly $[48,49]$, an advantage for survival and access to reproduction. On the other hand, morphological differences may be the result of growth impairment related to nutritional deficiencies $[18,45,50]$ or greater competition between individuals for access to resources [47]. Considering that a smaller size and weaker body condition may be indicators of poorer quality [44] due to a negative relationship with the reproduction [6,51] and survival of 
birds [52,53], these studies tend to show that urbanization contributes to a decrease in the quality of individuals.

Physiological and genomic changes are also observed in urban individuals, and several studies suggest environmental pressures on individual health and survival [29]. Telomeres, non-coding repeat sequences in the distal region of chromosomes, contribute to maintaining genetic integrity during cell division [54]. The attrition of telomeres determines the senescence of the cells [55]. The age-dependent attrition of telomeres is observed in many species [56], and thus telomere length and attrition rate can be considered as a marker of longevity $[57,58]$. In addition, exposure to chemical pollutants [59,60], noise pollution $[61,62]$ or excessive stress [63] contribute to accelerating the attrition of telomeres, in particular by influencing the oxidative status of individuals [64-67]. Telomere length is therefore representative of an individual's ability to maintain somatic integrity in the face of environmental constraints and to cope with the energetic cost of reproduction [4], thus reflecting individual quality [68]. Although some studies have shown that urban individuals have shorter telomeres than forest individuals [69], our previous results (Saulnier et al., submitted) and another study showed an opposite pattern for Great Tits [70]. These results suggest that the urban environment plays a selective role, where only high-quality individuals are able to survive and/or reproduce in the city. In particular, in studies on Great Tits, breeders consist of individuals that have been able to invest energy in reproduction while being able to invest in self-maintenance because they are generally caught when nestlings are already 1 week old, when the risk of desertion is lowest. Birds that fail their reproduction early (egg laying or early hatching) are not included, and thus breeders are not representative of the general population. Another possibility to explain the longer telomeres in urban breeders is, as telomeres tend to shorten with age, that birds are younger in the city than in the forest, with mature individuals either dying or migrating to more favorable sites less constraining for the reproduction.

The first aim of this study was therefore to determine whether the urban environment really plays a filtering role on the quality of the individuals living in this environment. In this context, we monitored an urban population and a forest population of Great Tits nesting in artificial nest boxes in the Eurometropole of Strasbourg (Alsace, France). Adult birds were caught during winter and spring in order to compare the quality of individuals in the population before the breeding period and the population of breeders for both sites. The quality of birds was assessed using telomere length, morphology and reproductive success of birds. Following the hypothesis of the filtering role of the urban environment on bird quality, we expected to observe longer telomeres, larger size and better body condition for individuals captured during the breeding period compared to individuals captured in winter in the city, whereas no difference would be detected in the forest population. Based on molting pattern, the age category of the individuals ( 2 years old young breeders versus older breeders $>2$ years old) was also estimated in order to test the hypothesis of younger breeders. The second aim of this study was to test the existence of reproductive costs in terms of body condition and telomere length using the longitudinal data of individuals captured in winter and recaptured during the breeding period. Considering higher reproductive constraints in the city, we expected a greater decrease in body condition and telomere length in the urban site than the forest site.

\section{Materials and Methods}

\subsection{Study Site and Animal Sampling}

This study, conducted between February and June 2019, is part of a long-term monitoring of populations of the Great Tits (Parus major) living in artificial nest boxes along an urbanization gradient in the Eurometropole of Strasbourg (Alsace, France). The Great Tit is a common passerine that breeds easily in artificial nest boxes, facilitating the monitoring of reproduction and adult captures. Moreover, this species is considered to be an urban adapter, and is able to live in both anthropogenic and natural areas. Great Tits breed between April and June and lay, on average, 7.5 eggs in the city and 9 eggs in forests (in our 
populations, Saulnier et al., submitted), which are incubated for approximately 13 days. Two populations were monitored: an urban population living in different urban parks and tree-lined walkways in the core area of Strasbourg (48.5793 N; 7.7677 W, population density $=3488$ inhab. $/ \mathrm{km}^{2}$ ), and a forest population living in La Wantzenau forest within $12-20 \mathrm{~km}$ of Strasbourg ( $48.6480 \mathrm{~N} ; 7.8337 \mathrm{~W}$, population density $\left.=231 \mathrm{inhab} . / \mathrm{km}^{2}\right)$. The urban site is characterized mostly by no-vegetation (roads, bare rock, soil, and building) and low-vegetation (herbaceous and small bushes) surfaces, whereas the forest site is an alluvial forest composed of tree species such as ash, beech, sycamore, maple, and oak. Some of our previous results (Saulnier et al., submitted) show that the pollutant concentrations of the two sites are similar. However, concerning the food availability, urban birds are often fed at bird feeders in winter by residents, especially in urban parks, but the invertebrate abundance is 1.5- to 2-times less than in forests during reproduction.

Individuals from both sites were captured during two sessions: one in winter (between February and March), after birds disperse but before breeding, and one during reproduction (first clutch, April-May). Great Tits are mostly insectivorous during the breeding period, but in winter they are granivorous, and are frequently found near bird feeders. Two methods were used simultaneously to capture individuals in winter. The first method consisted of using trap feeders placed as close as possible to areas where humans fed birds (mostly for urban sites). The second method was the use of mist nets with dimensions of $10 \times 2.5 \mathrm{~m}$ placed preferentially near dense vegetation areas. The low vegetation cover made the nets overtly visible to the birds in urban sites, and the majority of urban individuals were caught with the trap feeders (21/28 individuals). On contrary, in the forest site, birds are not accustomed to feeders and no birds were captured with the trap feeder. During the breeding period, adults were captured using a trapdoor system installed at the entrance to the nest boxes. The capture occurred when nestlings were between 8 and 16 days old (before 8 days, nest desertion probability is high and after 16 days, the risk of early fledging is very high). Thus, we only captured birds that successfully raised nestlings until 8 days old. During the breeding season, we also monitored the reproduction of birds to estimate the breeding success. For each occupied nest box, we recorded the laying date, the clutch size, the hatching date $( \pm 0.5 \mathrm{~d})$, the number of hatchings and the number of fledglings. The number of hatchings was calculated as the difference between clutch size and the number of unhatched eggs. Thirty nest boxes were occupied by Great Tits among the 92 monitored boxes in the urban site, and 36 nest boxes were occupied among the 65 monitored boxes in the forest site (see Appendix A for more details on nest box occupation rate). Only 3 nests were deserted before hatching, all in the city. Several desertions at the nestling stage were observed in both sites: 7 and 2 nests were deserted in the urban and forest sites, respectively. One nest was also predated in the forest site, but before the capture of adults. The nest predation rate in our study sites was relatively low, and did not exceed 2 to 3 nests per year and per site. The major predators observed were domestic cats in the city and some Mustelidae species in the forest.

All captured individuals were ringed with a metal ring for identification. The recapture rate of fledglings in the recruited population was very low, and the number of individuals with known age was only 12 birds ( 4 and 8 birds in the urban and forest sites, respectively). For this reason, the age of birds was estimated from the color of the primary coverts on the wings. This technique allowed a distinction between individuals in their second year ( 2 years old or 2 y.o.) with a partial post-juvenile molt (bluish edges only in greater coverts) of the previous year from older individuals ( $>2$ years old or $>2$ y.o.) with a complete postbreeding molt and all wing feathers with bluish edges (see Appendix $B$ for more details on sample size). Individuals were also sexed using the width of the ventral black tie (larger for males), but also with the presence of a brood patch for females during reproduction.

Several morphometric measurements were used to estimate the body size and body condition of the birds: body mass, measured with a precision balance $( \pm 0.1 \mathrm{~g})$, tarsus length and head-to-beak distance (from the back of the head to the tip of the beak), measured with a caliper $( \pm 0.1 \mathrm{~mm})$ and length of closed, flattened wing, measured with a ruler $( \pm 0.5 \mathrm{~mm})$. 
Finally, for each individual, we took a blood sample $(75 \mu \mathrm{L})$ from the brachial vein using a heparinized capillary after skin breach with a sterile needle. In the field, the blood samples were kept at $+4{ }^{\circ} \mathrm{C}$ in a cooler. At the end of each daily field session, the samples were centrifuged at $4000 \times g$ for $10 \mathrm{~min}$ to separate the plasma from the erythrocytes. Then, samples were stored at $-80^{\circ} \mathrm{C}$ until laboratory analysis.

In winter, 28 individuals were captured in the city and 30 in the forest. Among these individuals, 16 were recaptured during the breeding period in the urban site and 15 in the forest site. During the breeding season, 31 individuals not previously captured in winter were also captured in the urban site and 40 in the forest site. This work was conducted in accordance with the guidelines of the French legislation concerning the capture and biological sampling of wildlife, and was approved by the Bas-Rhin department prefect, a French national ethical committee and the CRBPO (National Museum of Natural History)—see more details in the Institutional Review Board Statement.

\subsection{Relative Telomere Length Analysis}

The relative telomere length (RTL) was measured using a quantitative polymerase chain reaction (qPCR) from DNA extracted from the erythrocytes of birds. This method gives a relative length corresponding to a ratio between the length of amplified telomeres sequence $(\mathrm{T})$ and the length of an amplified control gene sequence $(S)$, which is identical for all individuals. The control gene used for this species is the Parus major zinc finger protein (ZENK) gene (GenBank: EF568148). The qPCR method for RTL measurement in the bird was described and validated by Criscuolo et al. [71].

The DNA extraction was realized on a column using the NucleoSpin@ Blood Quick Pure (Macherey-Nagel@, Düren, Germany) kit from erythrocytes diluted at 1:40 in PBS $1 X$. The qPCR was performed on a 96-well plate. The reaction volume in each well was $10 \mu \mathrm{L}$ with $2 \mathrm{ng}$ of DNA. Each sample was measured in duplicate, and on each plate, an inter-plate control sample, a negative control (DNAse-free water), and a standard range obtained by the cascade dilution of a DNA control $(8,4,2,1$ and $0.5 \mathrm{ng})$ as a control of amplification efficiency were deposited. Amplification of telomere sequences and the control gene took place on separate plates. The amplification cycle was performed with a final volume of $10 \mu \mathrm{L}$ per well with $2 \mathrm{ng}$ of DNA $(2 \mu \mathrm{L})$, and $8 \mu \mathrm{L}$ of reaction mix containing a GoTaq ${ }^{\circledR}$ qPCR (Promega, Madison, WI, USA). For the control gene, amplification started with 2 min at $95{ }^{\circ} \mathrm{C}$, followed by 40 cycles of $15 \mathrm{~s}$ at $95{ }^{\circ} \mathrm{C}, 30 \mathrm{~s}$ at $56^{\circ} \mathrm{C}$ and $1 \mathrm{~min} 30 \mathrm{~s}$ at $72{ }^{\circ} \mathrm{C}$. The conditions of telomere amplification were similar except for the number of cycles and the elongation step: 30 cycles of $15 \mathrm{~s}$ at $95^{\circ} \mathrm{C}, 30 \mathrm{~s}$ at $56^{\circ} \mathrm{C}$ and $30 \mathrm{~s}$ at $72{ }^{\circ} \mathrm{C}$. Both assays were followed by melting curve analysis. Primers sequences are provided in Appendix C. The mean efficiency of amplification for the control gene was $97.5 \pm 4.9 \%$ and $99.9 \pm 4.5 \%$ for telomeres. The mean intra-individual Cq (number of cycles necessary to detect amplified DNA above basal signal) variation was $1.50 \pm 1.33 \%$ for the control assay and $2.51 \pm 2.39 \%$ for the telomere assay. The mean inter-run $\mathrm{Cq}$ variation was $2.40 \%$ and $4.90 \%$ for the control gene and telomeres, respectively. In total, 151 samples were analyzed. Ten birds were excluded from the telomere analysis either because (1) we did not manage to obtain a sufficient amount of blood $(n=7)$, or $(2)$ the sample quality was not sufficient $(n=3)$. These individuals were excluded from the telomere analysis.

\subsection{Statistical Analysis}

Statistical analyses were performed using $\mathrm{R}$ software (version 4.1.0, [72]) with a significance threshold set to $\alpha=0.05 \%$. All tested models were followed with type II ANOVA, and post hoc significance effects of interaction, or factor variables, were tested using Tukey tests. The model application conditions were tested using the Kolmogorov-Smirnov test (normality), the Levene test (homoscedasticity), and the collinearity test (variance inflation factor < 5). For all analyses, telomeres were z-transformed [73], and the hatching date was expressed as the relative day from 1 March. 
Tarsus length, head-to-beak distance and wing length were scaled and included in a principal component analysis (PCA) to estimate a body size index for each bird. The body size index corresponded to the first dimension of the PCA and explained $62.26 \%$ of the total variation. This body size index was used to estimate the body condition of birds, which corresponded to the residuals of the linear regression between body mass and body size index $\left(\mathrm{R}^{2}=0.37, p<0.001\right)$. The residuals of body mass associated with the integrative measure of structure size is a reliable size-independent index of body condition [74,75]. We aimed to compare the quality of birds between seasons and sites. To address this aim, we used mixed models with the entire dataset, i.e., including all caught birds. The differences in age class were tested using a generalized linear mixed model with a binomial family (function glmer (package lme4 [76]), 0: 2 y.o. birds, 1: $>2$ y.o. birds). The differences in body condition, body size index and RTL were tested using $\mathrm{T}$ linear mixed models (function lmer, package lme4). In all models, bird ID was included as a random factor to take into account recaptures. Each model included the following covariates: the site (urban or forest), the season (winter or reproduction), the sex, the interaction between site and season, and the interaction between site and sex. For body size index, body condition and RTL, the age and the interaction between sites and age was also included in the models. For RTL, the body condition was also included in the model. Non-significant interactions were removed sequentially.

The second aim was to test the individual changes in telomere length and body condition with longitudinal data. For this, we used only a subset of the dataset, including only birds that were captured on both occasions. Changes in body condition and RTL were calculated by subtracting the measure made during breeding to the measure made during winter. Linear models (function $\mathrm{lm}$ ) included the site, the sex and the age as explanatory variables, but also the fledgling number and the hatching date, to take into account reproductive investment and the timing of breeding. For the RTL model, winter RTL was also included to take into account the initial telomere length in telomere attrition.

\section{Results}

Age of captured birds was significantly different between sex, whatever the season or the site (Table 1, also see Appendix D for estimates). Captured females were younger than captured males (Tukey, $p<0.001$ ). For body condition, none of the tested variables were significant (Table 1, also see Appendix D for estimates).

Table 1. Result of statistical analyses of morphological and genomic parameters between urban and forest birds and between seasons (winter and reproduction).

\begin{tabular}{|c|c|c|c|c|c|c|c|c|c|c|c|c|}
\hline \multirow[b]{2}{*}{ Variable } & \multicolumn{3}{|c|}{ Age $(n=161)$} & \multicolumn{3}{|c|}{$\begin{array}{l}\text { Body Size Index } \\
\quad(n=161)\end{array}$} & \multicolumn{3}{|c|}{$\begin{array}{l}\text { Body Condition } \\
\quad(n=161)\end{array}$} & \multicolumn{3}{|c|}{ RTL $(n=151)$} \\
\hline & $\mathrm{Chi}^{2}$ & df & $p$ & $\mathbf{F}$ & df & $p$ & $F$ & df & $p$ & F & df & $p$ \\
\hline Site & 0.156 & 1,154 & 0.693 & 45.66 & 1,153 & $<0.001$ & 0.6002 & 1,149 & 0.440 & 0.548 & 1,142 & 0.461 \\
\hline Sex & 61.35 & 1,154 & $<0.001$ & 39.97 & 1,153 & $<0.001$ & 1.6297 & 1,149 & 0.203 & 0.395 & 1,142 & 0.531 \\
\hline Season & 0.400 & 1,154 & 0.527 & 4.46 & 1,153 & 0.042 & 3.9457 & 1,149 & 0.051 & 0.623 & 1,142 & 0.432 \\
\hline Age & & & & 5.82 & 1,153 & 0.017 & 1.1800 & 1,149 & 0.280 & 0.812 & 1,142 & 0.370 \\
\hline $\begin{array}{l}\text { Body condition } \\
\text { Site } \times \text { Age }\end{array}$ & & & & & & & & & & 0.577 & 1,142 & 0.450 \\
\hline $\begin{array}{c}\text { Site } \times \text { Season } \\
\text { Site } \times \text { Sex }\end{array}$ & & & & 4.18 & 1,153 & 0.048 & & & & 4.525 & 1,142 & 0.037 \\
\hline
\end{tabular}

Note: RTL means relative telomere length. Significant values (under $p=0.05$ ) are in bold.

For the body size index, a significant interaction between the season and the site was observed (Table 1, Figure 1, Appendix C). Forest birds were larger than urban birds in both seasons (Tukey, all $p<0.001$ ). However, the difference was more important during the reproduction season. In the urban environment, individuals captured during the reproductive season were smaller than birds captured during the winter (Tukey, $p=0.005$ ). The 
body size index also varied significantly according to the age of birds-young individuals tended to be smaller than older ones (Tukey, $p=0.02$ ). A significant effect of sex was also observed, with smaller females than males (Tukey, $p<0.001$ ).

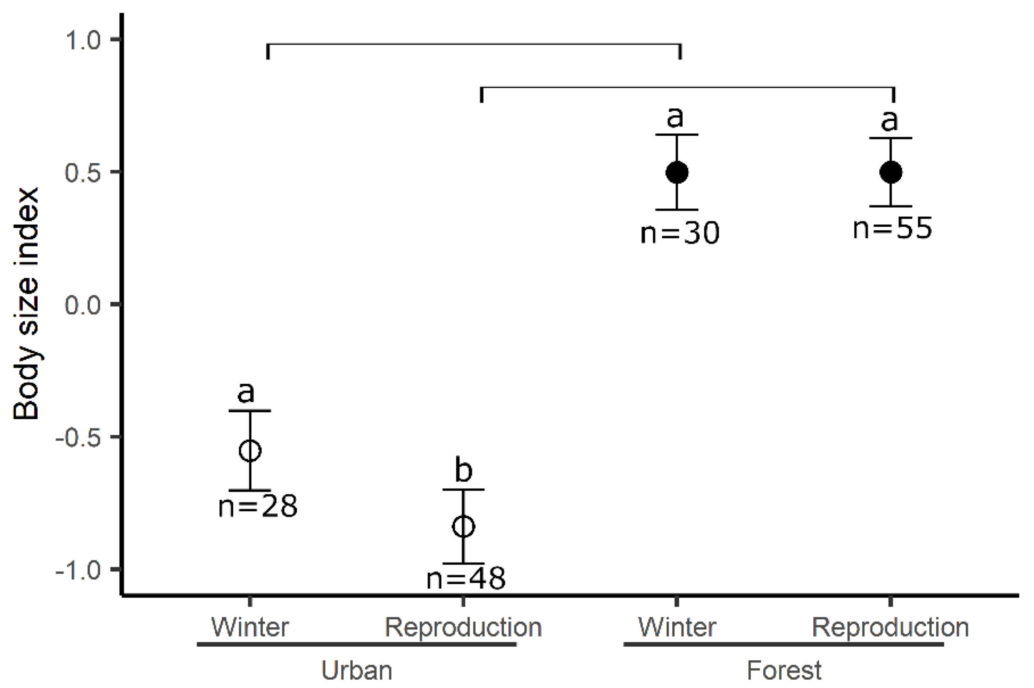

Figure 1. The body size of birds between sites across seasons. Means and standard errors are represented. Different letters represent significant differences between seasons for the same site and bars represent the difference between sites for the same season (see text for details).

The interaction between the season and the site was also significant for RTL (Table 1, Figure 2, see also Appendix D for estimates). Urban birds in winter had longer telomeres than urban birds captured during reproduction (Tukey; $p=0.039$ ) and forest birds in winter (Tukey, $p=0.034$ ). No site-dependent differences in telomeres were observed during reproduction (Tukey, $p=0.48$ ).

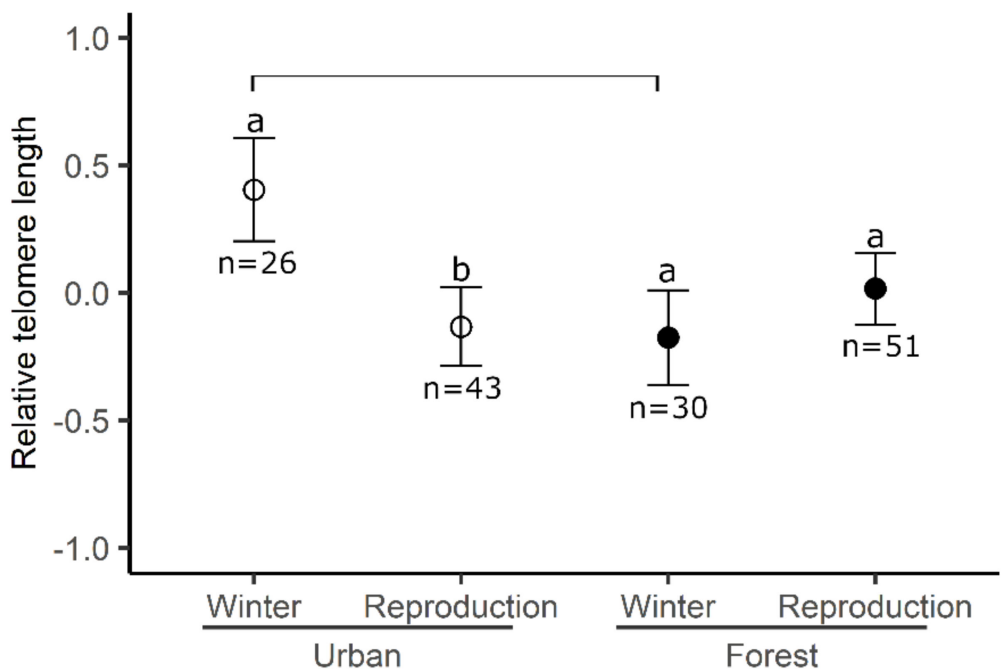

Figure 2. The relative telomere length of birds between sites across seasons. Means and standard errors are represented. Different letters represent significant differences between seasons for the same site and bars represent the difference between sites for the same season (see text for details).

Ultimately, we analyzed variation in body condition and RTL for birds captured in both seasons. None of the tested variables significantly explained change in body condition or change in RTL between winter and reproduction (Table 2, also see Appendix D for estimates). 
Table 2. Result of statistical analyses of morphological and genomic parameters changes between seasons for re-caught birds.

\begin{tabular}{ccccccc}
\hline & \multicolumn{3}{c}{ Body Condition $(\boldsymbol{n = 2 7 )}$} & \multicolumn{3}{c}{ RTL $(\boldsymbol{n = 2 3 )}$} \\
\hline Variable & $\mathbf{F}$ & $\mathbf{d f}$ & $\boldsymbol{p}$ & $\mathbf{F}$ & $\mathbf{d f}$ & $\boldsymbol{p}$ \\
\hline Site & 0.048 & 1,21 & 0.829 & 0.161 & 1,16 & 0.694 \\
Sex & 0.523 & 1,21 & 0.478 & 1.105 & 1,16 & 0.310 \\
Age & 2.287 & 1,21 & 0.146 & 0.069 & 1,16 & 0.796 \\
Fledging number & 0.850 & 1,21 & 0.367 & 0.689 & 1,16 & 0.419 \\
Hatching date & 0.111 & 1,21 & 0.742 & 2.778 & 1,16 & 0.115 \\
RTL Winter & & & & 0.527 & 1,16 & 0.479 \\
\hline
\end{tabular}

Note: RTL means relative telomere length.

\section{Discussion}

No differences in body condition were observed between sites or seasons. The body condition before breeding is correlated with breeding success [51,77] due to the high energetic requirements associated with reproduction. Nevertheless, a difference in body condition is not consistently observed in studies on urbanization in different bird species, especially for adult birds [29]. The lack of prey in cities is compensated for by anthropogenic food, which is more reliable and abundant. However, human-provided foods are often of poor quality compared to natural ones, often containing an inadequate protein content, and can lead to potential physiological impairments [78]. However, our study highlighted that urban individuals had a smaller body size than forest individuals, whatever the season, and that, for the urban site only, birds captured during breeding were smaller than birds captured during winter. The smaller size of urban individuals is a common pattern, and has been found in many studies [79-81]. Several hypotheses can explain this result. Some studies tend to show that smaller size is a response to microclimates and urban heat islands according to Bergmann's law [46]. Urban pressures during the early stages of life can also lead to growth delays and impairment $[18,50]$ that may still be visible in adulthood. Other studies highlight the advantages of a smaller size in an urban environment. In fact, a smaller size improves the maneuverability of birds, but also the climb rate and the maximum speed [82]. The flight performance improvement can ensure better mobility in a complex and fragmented urban matrix, but it also ensures better avoidance of predators $[44,83,84]$. Following this hypothesis, the smaller body size of urban breeders compared to winter birds suggests that the urban environment would have a filtering role based on bird morphology, with a smaller size conferring an advantage regarding reproduction success, potentially since these birds are more agile or less prone to predation. Therefore, these size differences are either the result of micro-evolutionary processes or due to phenotypic plasticity resulting from environmental constraints, as demonstrated in a different population of the same species [80]. Further studies are required to determine the selective pressure exerted by the urban environment on the body size, for example by testing the correlation between body size and survival.

Our results also point to a positive relationship between body size and the age of birds, whatever the site or season. As the body size index is partly correlated with the wing size, this relationship may be the result of feather quality and molt stage of the birds. This hypothesis is supported by a correlation observed between wing lengths and age in a study on common blackbirds [46]: younger blackbirds tended to have shorter wings than older birds. In fact, for multiple passerine species, including Great Tits, feather quality and length tend to increase between the post-fledging partial molt and the post-breeding adults molts $[85,86]$. However, no age-distribution difference between sites or seasons were observed, suggesting that smaller breeders occur regardless of the age of birds. No difference in age distributions also suggests that, although the urban environment imposes high reproductive constraints [28], both experimented and non-experimented birds have the potential to reproduce and may succeed. 
The direction of the change in telomere length in urban birds was opposite to that in our prediction concerning the filter hypothesis for the city. In fact, our results demonstrate longer telomeres for urban individuals in winter compared to the breeding period. On the other hand, as expected by the filter hypothesis, no difference between season was detected in forest birds for this parameter. Long telomeres are generally associated with a better health and survival [57,87] and longevity [88], and can be considered as a quality index for most animal species. Longer telomeres for urban birds during winter might suggest that environmental pressures favor individuals that can manage their somatic maintenance in harsh environments such as in the city compared to forests. However, the hypothesis of younger individuals in the city cannot be totally excluded either. Although our models did not show any difference in proportions of individuals in the 2 y.o. and $>2$ y.o. categories, it is possible that age differences exist within the $>2$ y.o. category. In this case, longer telomeres in winter in urban birds would be the consequence of higher mortality or emigration of older birds. These populations of Great Tits have been followed since 2015, but the recapture rate is still very low, restricting longitudinal studies based on known age. To test our hypothesis concerning the age effect on telomere attrition rate, this experiment should be carried out over several years on known-age birds.

In addition, the lack of difference in telomere length between sites during the breeding season is not consistent with a previous study on the same species that showed that telomeres were longer in urban than in forest birds [70]. Nevertheless, we showed in a previous study on the same population longer telomeres in urban breeders (Saulnier et al., submitted), but not every year. In fact, this study showed that the different length of telomeres between urban and forest breeders was not significant during years with harsh weather conditions. During the year of the present study, despite a high hatching success $(89.4 \%$ in the city and $97 \%$ in the forest site), the number of fledglings was very low in the city (4.5 in the city and 7.1 in the forest), notably because of cold temperatures during rearing. Some studies highlighted the impact of reproductive costs on telomere length $[4,89,90]$ through a trade-off between reproductive investment and somatic maintenance [4]. Harsh weather conditions during rearing might increase the reproductive cost related to the foraging of birds faced with the increased energy requirements of nestlings for thermoregulation [91], but also to a decrease in prey availability [92]. Then, the shorter telomeres observed in urban individuals during the breeding season therefore seem to reflect the higher cost of breeding in years with unfavorable weather conditions. The absence of a seasonal change in telomere length in re-caught birds and the absence of a correlation with the fledging number may not seem consistent with this hypothesis. Nevertheless, the sample size of re-caught birds was small, and this study was realized during a single year. It would be interesting to carry out this experiment across several years with contrasting weather conditions to properly understand the correlations between telomere length, reproductive costs and weather in the city.

Additionally, a potential influence of the capture technique on the seasonal variation of telomere length and body size pattern cannot be excluded. The trap feeder system required the birds to enter into a cage. It is conceivable that this system may select for bolder and lesser neophobic birds, or that there is a specific cognition aspect where the mist net and nest box capture techniques are more random and less selective. Some studies on birds showed that bolder birds had a lower maximum corticosterone concentration [93], higher antioxidant capacity $[67,94]$ and also a lower concentration of reactive oxygen metabolites, leading to lower oxidative stress. The observation of higher telomere length for urban birds in winter might therefore be due to the selection of birds with a higher capacity for self-maintenance or less metabolic cost, impacting telomeres. In the same way, the trap feeders were placed on artificial food supply spots, which are an essential part of the winter diet of urban birds. It could be conceivable that bigger individuals, requiring higher energy requirements, favor these spots more than smaller individuals, thereby increasing their chance of being caught. 


\section{Conclusions}

In conclusion, our results reveal morphological and genomic differences between winter individuals and breeders, but the question of the filtering role of the city remains open. If we consider that a smaller size confers an advantage in an urban environment, and that smaller individuals are of greater quality, then the urban environment does indeed have a filtering role on the quality of individuals. However, more studies are necessary to confirm the advantage of a smaller body size in the city, especially to test the correlation between body size and bird survival. However, the results obtained for telomere length during the reproduction period do not support the filter hypothesis. These results rather support a higher cost of reproduction in the city dependent on weather conditions. Longterm studies are therefore necessary to improve the understanding of selection mechanisms that take place in cities and the dynamics associated with inter-annual weather variations.

Author Contributions: Conceptualization, A.S., J.B. and S.M.; methodology, A.S., J.B., S.Z. and S.M.; validation, A.S., J.B. and S.M.; formal analysis, A.S.; investigation, A.S., J.B., P.U., G.L., S.Z. and S.M.; resources, J.B. and S.M.; data curation, A.S.; writing-original draft preparation, A.S., J.B. and S.M.; writing-review and editing, A.S., J.B., P.U., G.L., S.Z. and S.M.; visualization, A.S.; supervision, S.M.; project administration, J.B. and S.M.; funding acquisition, S.M. All authors have read and agreed to the published version of the manuscript.

Funding: This research received no external funding. A.S. is the recipient of a PhD grant from the French Ministry of Research.

Institutional Review Board Statement: The study was conducted according to the guidelines of the French legislation concerning the capture and biological sampling of wildlife, and was approved by the Bas-Rhin department prefect (since 2015), the French regional ethical committee $n^{\circ} 35$ (project APAFIS\# 9160-2017030316182730 v2, 2017), and S.M., J.B., A.S. and P.U. received ringing licenses and authorizations for blood sampling from the CRBPO (National Museum of Natural History) as part of a research program led by SM (PP $\left.\mathrm{N}^{\circ} 673\right)$ obtained in 2014.

Informed Consent Statement: Not applicable.

Data Availability Statement: The dataset is part of a long-term study that is still ongoing and not yet deposited in a repository. However, it will be available on request, so please contact us.

Acknowledgments: We would like to thank Noé Rehspringer and Natacha Garcin and all students who assisted in the field and contributed to collecting and analyzing data. We thank our editor, Jukka Jokimäki, and our two reviewers for their useful comments on this manuscript. We also thank the Universite de Strasbourg, the Eurometropole of Strasbourg, and the associations Société Régionale de Protection des Oiseaux (S.R.P.O) and Campus Vert.

Conflicts of Interest: The authors declare no conflict of interest.

\section{Appendix A}

Table A1. Geographical Coordinates of the Nest Box Groups on each Site.

\begin{tabular}{ccccc}
\hline Site & Groupe & Coordinates (Lat. Long.) & Type & Nb Nestboxes \\
\hline Urban & Campus 1 & $48.5843 \mathrm{~N} ; 7.7637 \mathrm{~W}$ & Urban square & 26 \\
& Campus 2 & $48.5794 \mathrm{~N} ; 7.7677 \mathrm{~W}$ & Busy road & 11 \\
& Citadelle & $48.5759 \mathrm{~N} ; 7.7748 \mathrm{~W}$ & Urban park & 40 \\
& Heyritz & $48.5727 \mathrm{~N} ; 7.7442 \mathrm{~W}$ & Urban square & 15 \\
\hline Forest & La Wantzenau & $48.6480 \mathrm{~N} ; 7.8337 \mathrm{~W}$ & Alluvial forest & 65 \\
\hline
\end{tabular}




\section{Appendix B}

Table A2. Number of Birds in each Age Category at Different Seasons for Urban and Forest Site.

\begin{tabular}{cccccccccccccc}
\hline & \multicolumn{4}{c}{} & \multicolumn{4}{c}{ Urban } & \multicolumn{3}{c}{ Forest } \\
\hline & & Winter & \multicolumn{4}{c}{ Reproduction } & & Winter & \multicolumn{3}{c}{ Reproduction } \\
\hline & F & M & Total & F & M & Total & F & M & Total & F & M & Total \\
\hline 2 years old & 4 & 7 & 11 & 16 & 5 & 21 & 8 & 6 & 14 & 20 & 9 & 29 \\
$>$ 2 years old & 5 & 12 & 17 & 9 & 18 & 27 & 4 & 12 & 16 & 12 & 14 & 26 \\
$\quad$ Total & 9 & 19 & 28 & 25 & 23 & 48 & 12 & 18 & 30 & 32 & 23 & 55 \\
\hline
\end{tabular}

\section{Appendix C}

Table A3. Primers Sequence for qPCR RTL Analysis.

\begin{tabular}{lll}
\hline & Forward & Reverse \\
\hline $\begin{array}{l}\text { Control gene } \\
\begin{array}{l}\text { P. major Zinc finger } \\
\text { protein }\end{array}\end{array}$ & ZENK1: 5'-TACATGTGCCATGGTTTTGC-3' & ZENK2:5'-AAGTGCTGCTCCCAAAGAAG-3' \\
$\begin{array}{ll}\text { GenBank:EF568148) } \\
\text { Telomeres }\end{array}$ & Tel1b: & Tel2b: \\
\hline
\end{tabular}

\section{Appendix D. Estimates of Generalized Linear Model Used for Morphological and Physiological Parameters}

Table A4. Difference of quality parameters between seasons for each site.

\begin{tabular}{ccccc}
\hline & Age & Body Size & Body Condition & \multicolumn{2}{c}{ Relative Telomere Length } \\
\hline & Estimate (SE) & Estimate (SE) & Estimate (SE) & Estimate (SE) \\
\hline Intercept & $-9.17(1.96)$ & $-0.9(0.2)$ & $0.07(0.17)$ & $0.27(0.25)$ \\
Site [Forest] & $-0.65(1.66)$ & $1.05(0.21)$ & $-0.1(0.13)$ & $-0.58(0.27)$ \\
Sex [M] & $20.67(2.67)$ & $1.11(0.17)$ & $-0.18(0.14)$ & $0.11(0.18)$ \\
Season [Reproduction] & $-0.92(1.45)$ & $-0.29(0.1)$ & $0.23(0.11)$ & $-0.54(0.25)$ \\
Age [2 years old] & & $-0.43(0.17)$ & $-0.15(0.14)$ & $0.16(0.17)$ \\
Body condition & & & & $0.08(0.11)$ \\
Site [Forest]:Season [Reproduction] & & $0.29(0.14)$ & & $0.73(0.34)$ \\
\hline
\end{tabular}

Table A5. Change of body condition and telomere length with reproduction for re-caught birds.

\begin{tabular}{ccc}
\hline & Body Condition & Relative Telomere Length \\
\hline & Estimate (SE) & Estimate (SE) \\
\hline Intercept & $-1.83(2.62)$ & $-3.83(2.46)$ \\
Site [Forest] & $-0.14(0.63)$ & $0.25(0.61)$ \\
Sex [M] & $0.27(0.38)$ & $-0.35(0.34)$ \\
Fledging number & $0.08(0.09)$ & $-0.06(0.07)$ \\
Hatching date & $0.02(0.05)$ & $0.08(0.05)$ \\
Age [2 years old.] & $0.56(0.37)$ & $-0.09(0.35)$ \\
RTL Winter & & $-0.03(0.23)$ \\
\hline
\end{tabular}

\section{References}

1. Stearns, S.C. The Evolution of Life Histories; Oxford University Press: Oxford, UK, 1992.

2. Lailvaux, S.P.; Husak, J.F. The life history of whole-organism performance. Q. Rev. Biol. 2014, 89, 285-318. [CrossRef] [PubMed]

3. McNamara, J.M.; Houston, A.I. State-dependent life histories. Nature 1996, 380, 215-221. [CrossRef] [PubMed]

4. Sudyka, J. Does reproduction shorten telomeres? Towards integrating individual quality with life-history strategies in telomere biology. BioEssays 2019, 41, 1900095. [CrossRef] 
5. Wilson, A.J.; Nussey, D.H. What is individual quality? An evolutionary perspective. Trends Ecol. Evol. 2010, 25, $207-214$. [CrossRef] [PubMed]

6. $\quad$ Blums, P.; Nichols, J.D.; Hines, J.E.; Lindberg, M.S.; Mednis, A. Individual quality, survival variation and patterns of phenotypic selection on body condition and timing of nesting in birds. Oecologia 2005, 143, 365-376. [CrossRef] [PubMed]

7. Vedder, O.; Bouwhuis, S. Heterogeneity in individual quality in birds: Overall patterns and insights from a study on common terns. Oikos 2018, 127, 719-727. [CrossRef]

8. Peralta-Sánchez, J.M.; Colmenero, J.; Redondo-Sánchez, S.; Ontanilla, J.; Soler, M. Females are more determinant than males in reproductive performance in the house sparrow Passer domesticus. J. Avian Biol. 2020, 51, e02240. [CrossRef]

9. Dukas, R. Animal expertise: Mechanisms, ecology and evolution. Anim. Behav. 2019, 147, 199-210. [CrossRef]

10. Forslund, P.; Pärt, T. Age and reproduction in birds-Hypotheses and tests. Trends Ecol. Evol. 1995, 10, 374-378. [CrossRef]

11. Pitera, A.M.; Branch, C.L.; Sonnenberg, B.R.; Benedict, L.M.; Kozlovsky, D.Y.; Pravosudov, V.V. Reproduction is affected by individual breeding experience but not pair longevity in a socially monogamous bird. Behav. Ecol. Sociobiol. 2021, 75, 1-11. [CrossRef]

12. Espie, R.H.M.; Oliphant, L.W.; James, P.C.; Warkentin, I.G.; Lieske, D.J. Age-dependent breeding performance in Merlins (Falco columbarius). Ecology 2000, 81, 3404-3415. [CrossRef]

13. Hamman, J.; Cooke, F. Age effects on clutch size and laying dates of individual female Lesser Snow Geese Anser caerulescens. Ibis 2008, 129, 527-532. [CrossRef]

14. Wiktander, U.; Olsson, O.; Nilsson, S.G. Age and Reproduction in Lesser Spotted Woodpeckers (Dendrocopos minor). Auk 2001, 118, 624-635. [CrossRef]

15. Hatch, M.I.; Westneat, D.F. Age-related patterns of reproductive success in house sparrows Passer domesticus. J. Avian Biol. 2007, 38, 603-611. [CrossRef]

16. Riechert, J.; Chastel, O.; Becker, P.H. Why do experienced birds reproduce better? Possible endocrine mechanisms in a long-lived seabird, the common tern. Gen. Comp. Endocrinol. 2012, 178, 391-399. [CrossRef]

17. Isaksson, C.; Andersson, S. Carotenoid diet and nestling provisioning in urban and rural Great Tits Parus major. J. Avian Biol. 2007, 38, 564-572. [CrossRef]

18. Biard, C.; Brischoux, F.; Meillère, A.; Michaud, B.; Nivière, M.; Ruault, S.; Vaugoyeau, M.; Angelier, F. Growing in cities: An urban penalty for wild birds? A study of phenotypic differences between urban and rural Great Tit chicks (Parus major). Front. Ecol. Evol. 2017, 5, 1-14. [CrossRef]

19. Vaugoyeau, M.; Adriaensen, F.; Artemyev, A.; Bańbura, J.; Barba, E.; Biard, C.; Blondel, J.; Bouslama, Z.; Bouvier, J.C.; Camprodon, J.; et al. Interspecific variation in the relationship between clutch size, laying date and intensity of urbanization in four species of hole-nesting birds. Ecol. Evol. 2016, 6, 5907-5920. [CrossRef]

20. Gil, D.; Brumm, H. (Eds.) Avian Urban Ecology; Oxford University Press: Oxford, UK, 2013; ISBN 9780199661572.

21. Jones, E.L.; Leather, S.R. Invertebrates in urban areas: A review. Eur. J. Entomol. 2012, 109, 463-478. [CrossRef]

22. Fenoglio, M.S.; Rossetti, M.R.; Videla, M. Negative effects of urbanization on terrestrial arthropod communities: A meta-analysis. Glob. Ecol. Biogeogr. 2020, 29, 1412-1429. [CrossRef]

23. MacLeod, R.; Barnett, P.; Clark, J.; Cresswell, W. Mass-dependent predation risk as a mechanism for house sparrow declines? Biol. Lett. 2006, 2, 43-46. [CrossRef]

24. Marzluff, J.M. Worldwide urbanization and its effects on birds. In Avian Ecology and Conservation in an Urbanizing World; Springer: Boston, MA, USA, 2001; pp. 19-47.

25. Sorace, A.; Gustin, M. Distribution of generalist and specialist predators along urban gradients. Landsc. Urban Plan. 2009, 90, 111-118. [CrossRef]

26. Rodewald, A.D.; Kearns, L.J. Shifts in dominant nest predators along a rural-to-urban landscape gradient. Condor 2011, 113, 899-906. [CrossRef]

27. Van Heezik, Y.; Smyth, A.; Adams, A.; Gordon, J. Do domestic cats impose an unsustainable harvest on urban bird populations? Biol. Conserv. 2010, 143, 121-130. [CrossRef]

28. Chamberlain, D.E.; Cannon, A.R.; Toms, M.P.; Leech, D.I.; Hatchwell, B.J.; Gaston, K.J. Avian productivity in urban landscapes: A review and meta-analysis. Ibis 2009, 151, 1-18. [CrossRef]

29. Sepp, T.; McGraw, K.J.; Kaasik, A.; Giraudeau, M. A review of urban impacts on avian life-history evolution: Does city living lead to slower pace of life? Glob. Chang. Biol. 2018, 24, 1452-1469. [CrossRef]

30. Wawrzyniak, J.; Glądalski, M.; Kaliński, A.; Bańbura, M.; Markowski, M.; Skwarska, J.; Zieliński, P.; Bańbura, J. Differences in the breeding performance of Great Tits Parus major between a forest and an urban area: A long term study on first clutches. Eur. Zool. J. 2020, 87, 294-309. [CrossRef]

31. Halfwerk, W.; Holleman, L.J.M.; Lessells, C.M.; Slabbekoorn, H. Negative impact of traffic noise on avian reproductive success. J. Appl. Ecol. 2011, 48, 210-219. [CrossRef]

32. Bailly, J.; Scheifler, R.; Berthe, S.; Clément-Demange, V.A.; Leblond, M.; Pasteur, B.; Faivre, B. From eggs to fledging: Negative impact of urban habitat on reproduction in two tit species. J. Ornithol. 2016, 157, 377-392. [CrossRef]

33. Peach, W.J.; Mallord, J.W.; Ockendon, N.; Orsman, C.J.; Haines, W.G. Invertebrate prey availability limits reproductive success but not breeding population size in suburban House Sparrows Passer domesticus. Ibis 2015, 157, 601-613. [CrossRef] 
34. Bailly, J.; Faivre, B.; Bernard, N.; Sage, M.; Crini, N.; Driget, V.; Garnier, S.; Rieffel, D.; Scheifler, R. Multi-element analysis of blood samples in a passerine species: Excesses and deficiencies of trace elements in an urbanization study. Front. Ecol. Evol. 2017, 5, 6. [CrossRef]

35. Isaksson, C.; Johansson, A.; Andersson, S. Egg yolk carotenoids in relation to habitat and reproductive investment in the Great Tit Parus major. Physiol. Biochem. Zool. 2008, 81, 112-118. [CrossRef] [PubMed]

36. Jarrett, C.; Powell, L.L.; McDevitt, H.; Helm, B.; Welch, A.J. Bitter fruits of hard labour: Diet metabarcoding and telemetry reveal that urban songbirds travel further for lower-quality food. Oecologia 2020, 193, 377-388. [CrossRef] [PubMed]

37. Hinsley, S.A.; Hill, R.A.; Bellamy, P.E.; Harrison, N.M.; Speakman, J.R.; Wilson, A.K.; Ferns, P.N. Effects of structural and functional habitat gaps on breeding woodland birds: Working harder for less. Landsc. Ecol. 2008, 23, 615-626. [CrossRef]

38. Estes, W.A.; Mannan, R.W. Feeding behavior of cooper's hawks at urban and rural nests in southeastern arizona. Condor 2003, 105, 107-116. [CrossRef]

39. Blair, R.B. Land use and avian species diversity along an urban gradient. Ecol. Appl. 1996, 6, 506-519. [CrossRef]

40. Clergeau, P.; Croci, S.; Jokimäki, J.; Kaisanlahti-Jokimäki, M.L.; Dinetti, M. Avifauna homogenisation by urbanisation: Analysis at different European latitudes. Biol. Conserv. 2006, 127, 336-344. [CrossRef]

41. McKinney, M.L. Urbanization as a major cause of biotic homogenization. Biol. Conserv. 2006, 127, 247-260. [CrossRef]

42. Croci, S.; Butet, A.; Clergeau, P. Does urbanization filter birds on the basis of their biological traits? Condor 2008, 110, 223-240. [CrossRef]

43. Kurucz, K.; Purger, J.J.; Batáry, P. Urbanization shapes bird communities and nest survival, but not their food quantity. Glob. Ecol. Conserv. 2021, 26, e01475. [CrossRef]

44. Liker, A.; Papp, Z.; Bókony, V.; Lendvai, Á.Z. Lean birds in the city: Body size and condition of house sparrows along the urbanization gradient. J. Anim. Ecol. 2008, 77, 789-795. [CrossRef]

45. Meillère, A.; Brischoux, F.; Parenteau, C.; Angelier, F. Influence of urbanization on body size, condition, and physiology in an urban exploiter: A multi-component approach. PLoS ONE 2015, 10, 1-19. [CrossRef]

46. Evans, K.L.; Gaston, K.J.; Sharp, S.P.; McGowan, A.; Hatchwell, B.J. The effect of urbanisation on avian morphology and latitudinal gradients in body size. Oikos 2009, 118, 251-259. [CrossRef]

47. Shochat, E. Credit or debit? Resource input changes population dynamics of city-slicker birds. Oikos 2004, 106, 622-626. [CrossRef]

48. Møller, A.P. Successful city dwellers: A comparative study of the ecological characteristics of urban birds in the Western Palearctic. Oecologia 2009, 159, 849-858. [CrossRef]

49. Caizergues, A.E.; Charmantier, A.; Lambrechts, M.M.; Perret, S.; Demeyrier, V.; Lucas, A.; Grégoire, A. An avian urban morphotype: How the city environment shapes Great Tit morphology at different life stages. Urban Ecosyst. 2021, 24, 929-941. [CrossRef]

50. Meillère, A.; Brischoux, F.; Henry, P.Y.; Michaud, B.; Garcin, R.; Angelier, F. Growing in a city: Consequences on body size and plumage quality in an urban dweller, the house sparrow (Passer domesticus). Landsc. Urban Plan. 2017, 160, 127-138. [CrossRef]

51. Milenkaya, O.; Catlin, D.H.; Legge, S.; Walters, J.R. Body condition indices predict reproductive success but not survival in a sedentary, tropical bird. PLoS ONE 2015, 10, e0136582. [CrossRef]

52. Lamb, J.S.; O'Reilly, K.M.; Jodice, P.G.R. Physical condition and stress levels during early development reflect feeding rates and predict pre-And post-fledging survival in a nearshore seabird. Conserv. Physiol. 2016, 4, cow060. [CrossRef]

53. Hõrak, P.; Tegelmann, L.; Ots, I.; Møller, A.P. Immune function and survival of Great Tit nestlings in relation to growth conditions. Oecologia 1999, 121, 316-322. [CrossRef]

54. Blackburn, E.H. Structure and function of telomeres. Nature 1991, 350, 569-573. [CrossRef]

55. Blackburn, E.H. Telomeres and telomerase: Their mechanisms of action and the effects of altering their functions. FEBS Lett. 2005, 579, 859-862. [CrossRef]

56. Tricola, G.M.; Simons, M.J.P.; Atema, E.; Boughton, R.K.; Brown, J.L.; Dearborn, D.C.; Divoky, G.; Eimes, J.A.; Huntington, C.E.; Kitaysky, A.S.; et al. The rate of telomere loss is related to maximum lifespan in birds. Philos. Trans. R. Soc. B Biol. Sci. 2018, 373, 20160445. [CrossRef] [PubMed]

57. Haussmann, M.F.; Mauck, R.A. Telomeres and longevity: Testing an evolutionary hypothesis. Mol. Biol. Evol. 2008, 25, 220-228. [CrossRef]

58. Monaghan, P.; Metcalfe, N.B.; Torres, R. Oxidative stress as a mediator of life history trade-offs: Mechanisms, measurements and interpretation. Ecol. Lett. 2009, 12, 75-92. [CrossRef]

59. Stauffer, J.; Panda, B.; Eeva, T.; Rainio, M.J.; Ilmonen, P. Telomere damage and redox status alterations in free-living passerines exposed to metals. Sci. Total Environ. 2017, 575, 841-848. [CrossRef]

60. Blévin, P.; Angelier, F.; Tartu, S.; Bustamante, P.; Herzke, D.; Moe, B.; Bech, C.; Gabrielsen, G.W.; Bustnes, J.O.; Chastel, O. Perfluorinated substances and telomeres in an Arctic seabird: Cross-sectional and longitudinal approaches. Environ. Pollut. 2017, 230, 360-367. [CrossRef] [PubMed]

61. Meillère, A.; Brischoux, F.; Ribout, C.; Angelier, F. Traffic noise exposure affects telomere length in nestling house sparrows. Biol. Lett. 2015, 11, 20150559. [CrossRef] [PubMed]

62. Grunst, A.S.; Grunst, M.L.; Bervoets, L.; Pinxten, R.; Eens, M. Proximity to roads, but not exposure to metal pollution, is associated with accelerated developmental telomere shortening in nestling Great Tits. Environ. Pollut. 2020, 256, 113373. [CrossRef] 
63. Young, R.C.; Welcker, J.; Barger, C.P.; Hatch, S.A.; Merkling, T.; Kitaiskaia, E.V.; Haussmann, M.F.; Kitaysky, A.S. Effects of developmental conditions on growth, stress and telomeres in black-legged kittiwake chicks. Mol. Ecol. 2017, 26, 3572-3584. [CrossRef]

64. Boonekamp, J.J.; Bauch, C.; Mulder, E.; Verhulst, S. Does oxidative stress shorten telomeres? Biol. Lett. 2017, $13,20170164$. [CrossRef] [PubMed]

65. Chatelain, M.; Drobniak, S.M.; Szulkin, M. The association between stressors and telomeres in non-human vertebrates: A meta-analysis. Ecol. Lett. 2020, 23, 381-398. [CrossRef] [PubMed]

66. Epel, E.S.; Blackburn, E.H.; Lin, J.; Dhabhar, F.S.; Adler, N.E.; Morrow, J.D.; Cawthon, R.M. Accelerated telomere shortening in response to life stress. Proc. Natl. Acad. Sci. USA 2004, 101, 17312-17315. [CrossRef] [PubMed]

67. Kim, S.-Y.; Velando, A. Antioxidants safeguard telomeres in bold chicks. Biol. Lett. 2015, 11, 20150211. [CrossRef] [PubMed]

68. Haussmann, M.F.; Winkler, D.W.; Vleck, C.M. Longer telomeres associated with higher survival in birds. Biol. Lett. 2005, 1, 212-214. [CrossRef] [PubMed]

69. Ibáñez-Álamo, J.D.; Pineda-Pampliega, J.; Thomson, R.L.; Aguirre, J.I.; Díez-Fernández, A.; Faivre, B.; Figuerola, J.; Verhulst, S. Urban blackbirds have shorter telomeres. Biol. Lett. 2018, 14, 20180083. [CrossRef] [PubMed]

70. Salmón, P.; Nilsson, J.F.; Watson, H.; Bensch, S.; Isaksson, C. Selective disappearance of Great Tits with short telomeres in urban areas. Proc. R. Soc. B Biol. Sci. 2017, 284, 20171349. [CrossRef]

71. Criscuolo, F.; Bize, P.; Nasir, L.; Metcalfe, N.B.; Foote, C.G.; Griffiths, K.; Gault, E.A.; Monaghan, P. Real-time quantitative PCR assay for measurement of avian telomeres. J. Avian Biol. 2009, 40, 342-347. [CrossRef]

72. R Development Core Team. R: A Language and Environment for Statistical Computing; R Foundation for Statistical Computing, Ed.; R Development Core Team: Vienna, Austria, 2021; ISBN 3-900051-07-0.

73. Verhulst, S. Improving comparability between qPCR-based telomere studies. Mol. Ecol. Resour. 2020, 20, 11-13. [CrossRef]

74. Labocha, M.K.; Hayes, J.P. Morphometric indices of body condition in birds: A review. J. Ornithol. 2012, 153, 1-22. [CrossRef]

75. Hayes, J.P.; Shonkwiler, J.S. Morphological indicators of body condition: Useful or wishful thinking? Body Compos. Anal. Anim. 2001, 10, 8-38. [CrossRef]

76. Bates, D.; Mächler, M.; Bolker, B.M.; Walker, S.C. Fitting linear mixed-effects models using lme4. J. Stat. Softw. 2015, 67, 1-48. [CrossRef]

77. Chastel, O.; Weimerskirch, H.; Jouventin, P. Influence of body condition on reproductive decision and reproductive success in the Blue Petrel. Auk 1995, 112, 964-972. [CrossRef]

78. Isaksson, C.; Andersson, M.N.; Nord, A.; Von Post, M.; Wang, H.L. Species-dependent effects of the urban environment on fatty acid composition and oxidative stress in birds. Front. Ecol. Evol. 2017, 5, 1-13. [CrossRef]

79. Corsini, M.; Schöll, E.M.; Di Lecce, I.; Chatelain, M.; Dubiec, A.; Szulkin, M. Growing in the city: Urban evolutionary ecology of avian growth rates. Evol. Appl. 2020, 14, 69-84. [CrossRef]

80. Caizergues, A.E.; Grégoire, A.; Charmantier, A. Urban versus forest ecotypes are not explained by divergent reproductive selection. Proc. R. Soc. B Biol. Sci. 2018, 285, 20180261. [CrossRef]

81. McDonnell, M.J.; Hahs, A.K. Adaptation and Adaptedness of Organisms to Urban Environments. Annu. Rev. Ecol. Evol. Syst. 2015, 46, 261-280. [CrossRef]

82. Hedenstrom, A.; Møller, A.P. Morphological adaptations to song flight in passerine birds: A comparative study. Proc. R. Soc. Lond. Ser. B Biol. Sci. 1992, 247, 183-187. [CrossRef]

83. Møller, A.P. Flight distance of urban birds, predation, and selection for urban life. Behav. Ecol. Sociobiol. 2008, 63, 63-75. [CrossRef]

84. Gosler, A.G.; Greenwood, J.J.D.; Perrins, C. Predation risk and the cost of being fat. Nature 1995, 377, 621-623. [CrossRef]

85. Kiat, Y.; Sapir, N. Life-history trade-offs result in evolutionary optimization of feather quality. Biol. J. Linn. Soc. 2018, 125, 613-624. [CrossRef]

86. Pap, P.L.; Barta, Z.; Tökölyi, J.; Vágási, I.C. Increase of feather quality during moult: A possible implication of feather deformities in the evolution of partial moult in the Great Tit Parus major. J. Avian Biol. 2007, 38, 471-478. [CrossRef]

87. Giraudeau, M.; Angelier, F.; Sepp, T. Do telomeres influence pace-of-life-strategies in response to environmental conditions over a lifetime and between generations? BioEssays 2019, 41, 1800162. [CrossRef]

88. Heidinger, B.J.; Blount, J.D.; Boner, W.; Griffiths, K.; Metcalfe, N.B.; Monaghan, P. Telomere length in early life predicts lifespan. Proc. Natl. Acad. Sci. USA 2012, 109, 1743-1748. [CrossRef]

89. Bauch, C.; Becker, P.H.; Verhulst, S. Telomere length reflects phenotypic quality and costs of reproduction in a long-lived seabird. Proc. R. Soc. B Biol. Sci. 2013, 280, 20122540. [CrossRef]

90. Angelier, F.; Weimerskirch, H.; Barbraud, C.; Chastel, O. Is telomere length a molecular marker of individual quality? Insights from a long-lived bird. Funct. Ecol. 2019, 33, 1076-1087. [CrossRef]

91. Krijgsveld, K.L.; Visser, G.H.; Daan, S. Foraging behavior and physiological changes in precocial quail chicks in response to low temperatures. Physiol. Behav. 2003, 79, 311-319. [CrossRef]

92. Avery, M.I.; Krebs, J.R. Temperature and foraging success of Great Tits Parus major hunting for spiders. Ibis 1984, 126, 33-38. [CrossRef] 
93. Atwell, J.W.; Cardoso, G.C.; Whittaker, D.J.; Campbell-Nelson, S.; Robertson, K.W.; Ketterson, E.D. Boldness behavior and stress physiology in a novel urban environment suggest rapid correlated evolutionary adaptation. Behav. Ecol. 2012, 23, 960-969. [CrossRef] [PubMed]

94. Herborn, K.A.; Coffey, J.; Larcombe, S.D.; Alexander, L.; Arnold, K.E. Oxidative profile varies with personality in European greenfinches. J. Exp. Biol. 2011, 214, 1732-1739. [CrossRef] [PubMed] 